\title{
A NEW GECKOID LIZARD FROM THE PHILIPPINE ISLANDS.
}

\section{By Leonhard Stejneger,}

Curator, Division of Reptiles and Batrachians, U. S. National Museum.

During a visit to some of the islands north of Luzon, composing the Babuyan group, Mr. R. C. McGregor, of the Science Bureau, Manila, collected on the islands of Fuga and Calayan a series of lizards which he kindly donated to the United States National Museum. $^{a}$ As might be expected, they belong to the families Gekkonidæ and Scincidæ, the latter being represented by numerous specimens of Mabuya multicarinata, Dasia smaragdina, and Sphenomorphus jagorii from both islands, besides a single Emoia atrocostata from Fuga. Of the geckos the collection contains Hemidactylus frenatus from both islands, Gekko monarchus from Calayan, and an undescribed species from the latter island. This new species evidently belongs to the genus Luperosaurus, and I take great pleasure in dedicating it to its discoverer, who has contributed so much to our knowledge of Philippine zoology.

\section{LUPEROSAURUS MACGREGORI, new species.}

Diagnosis.-No cutaneous fold along the sides of the body and very slight ones along the legs; tail not keeled laterally, nor flattened underneath.

Habitat.-Calayan Island, Philippine Archipelago.

Type.-Cat. No. 36191, U.S.N.M.; Calayan Island, Babuyan group; R. C. McGregor, collector.

Description of type specimen.-Male. Eye nearer the ear than the tip of the snout, its diameter about two-thirds of its distance from the latter; forehead slightly concave; ear-opening small, obliquely elliptic; digits half webbed; a very narrow dermal fold on each side of the legs, slightly better developed along the posterior side of the

${ }^{a}$ For an account of the trip and the islands see The Birds of Calayan and Fuga, Babuyan Group, by Richard C. McGregor, in Bull. Philippine Museum, No. 4, May 15, 1904, pp. 3-6.

Proceedings U. S. National Museum, Vol. XXXIII-No. 1576.

Proc. N. M. vol. xxxiii- $07-35$ 
femur, but not a trace of fold on sides of body or tail; tail not longer than body (without head), narrow, slightly depressed, not more flattened underneath than above; body and extremities above and below covered with minute granules, those on the underside of the tail slightly larger; rostral broad, rectangular, with a median triangular process above, in touch with a small median internasal between two wide supranasals; nostril between rostral, first supralabial, one small postnasal and two supranasals, the anterior of which are very wide and nearly meeting behind the rostral; 15 upper (14 on right side) and 14 lower labials; mental small, not distinguishable by size or shape from the other labials; no chin-shields, but the throat granules increase gradually in size toward the labials; a transverse group of somewhat enlarged granules a short distance in front of the vent, the posterior row bearing an uninterrupted series of 16 pores; tail above slightly annulate, each annulus marked posteriorly on the side by a slightly enlarged spine-like scale. Color (in alcohol) above dull russet clouded with indistinct dusky markings which are more or less longitudinal; underside whitish, slightly washed with russet.

\section{Dimensions.}

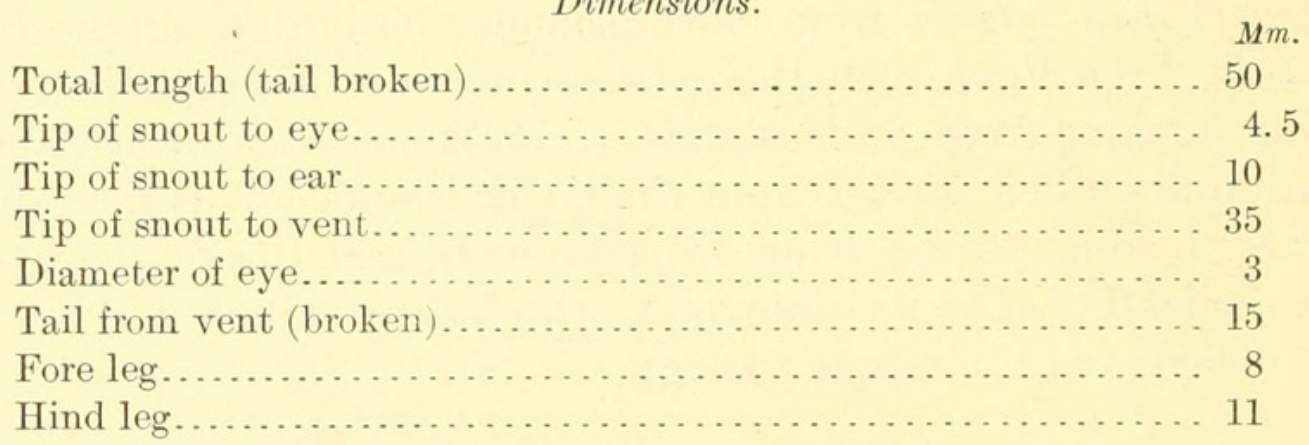

Remarks.-Besides the one described above, Mír. McGregor captured in the same place a very young specimen which in all essentials agrees with it. The tail is complete and equals the distance between the head and the vent. The chief difference in the scutellation consists in the large anterior supranasals being abbreviated by the separation of a small scale at the inner end, there being thus three internasals in touch with the rostral instead of one. The color is also essentially the same, but the russet color of the upper side, instead of gradually fading into a pale wash on the abdomen, invades the latter in the form of well-defined, but narrow, transverse, and somewhat wavy lines.

The present species seems to differ from the type of the genus Luperosaurus cumingii chiefly in the differently shaped tail and the total absence of a fold along the sides of the body. The latter is not specifically mentioned by Boulenger in his description (Cat. Liz. Brit. Mus., I, p. 181), but it is plainly shown in the figure (Plate XV, fig. 2). 


\section{$2 \mathrm{BHL}$ Biodiversity Heritage Library}

Stejneger, Leonhard. 1907. "A new geckoid lizard from the Philippine Islands." Proceedings of the United States National Museum 33(1576), 545-546. https://doi.org/10.5479/si.00963801.1576.545.

View This Item Online: https://www.biodiversitylibrary.org/item/53442

DOI: https://doi.org/10.5479/si.00963801.1576.545

Permalink: https://www.biodiversitylibrary.org/partpdf/51951

\section{Holding Institution}

Smithsonian Libraries

\section{Sponsored by}

Smithsonian

\section{Copyright \& Reuse}

Copyright Status: Public domain. The BHL considers that this work is no longer under copyright protection.

This document was created from content at the Biodiversity Heritage Library, the world's largest open access digital library for biodiversity literature and archives. Visit BHL at https://www.biodiversitylibrary.org. 